American Journal of Agricultural and Biological Sciences 5 (3): 321-330, 2010

ISSN 1557-4989

(C) 2010 Science Publications

\title{
The Practices of Contract Farming Among Fresh Fruit and Vegetable Suppliers in Malaysia
}

\author{
Norsida Man and Nolila Mohd Nawi \\ Department of Agribusiness and Information System, Faculty of Agriculture, \\ University Putra Malaysia, 43400 Serdang, Selangor, Malaysia
}

\begin{abstract}
Problem statement: Contract Farming (CF) concept is an agreement between buyers and producers, where by producers agree to produce and supply agriculture products according to the agreed quantity, quality, variety, grade, type of packaging and time of delivery. The two parties will mutually agree on the pricing of product, either on a contract price or a market price. Therefore, CF is seen as a tool for fostering smallholder participation in new high-value product markets and improving quality standards, thus increasing and stabilizing smallholder incomes. In Malaysia, CF has been identified as a system capable of stimulating agricultural production and was given a central role in the latest strategy by government to improve the vegetable and fruit production. Approach: The overall objective of this study was to examine $\mathrm{CF}$ as the new marketing practice among selected vegetable and fruit suppliers. The specific objectives of the study were: (1) to examine the respondents' perception towards CF; (2) to identify respondents' practices toward the CF and (3) to suggest a policy to ensure the sustainability of CF. Results: Out of 208 of the total respondents selected in the study, 41 suppliers were involved in CF. The data were analyzed using SPSS to describe the respondents' profile and current supply chain practices. At present, the suppliers have a contract agreement with Federal Agriculture Marketing Authority (FAMA) and FAMA has a contract agreement with Hypermarkets. It is presumed that there is a new supply chain network but the contract was not according to the FAO definition. The production and marketing contracts exist in non-formal or mainly verbal agreement. The production contract respondents also did not follow the criteria of CF. Conclusion: Because of this, all the non-formal production contracts in this survey are categorized into marketing contracts. This study concludes with the absence of proper farming contract between farmers and hypermarkets.
\end{abstract}

Key words: Contract farming, Fresh Fruit and Vegetable (FFV), marketing practices

\section{INTRODUCTION}

Agro-food systems are undergoing rapid transformation in Malaysia. Increased concentration in processing, trading, marketing and retailing is being observed in all regions of the country and in all segments of production-distribution chains. The traditional way in which food is produced, without farmers having a clear idea in advance of when, to whom and at what price they are going to sell their crops, is being replaced by practices more akin to consumers' needs, with far greater coordination between respondents, processors, retailers and others in the supply chain. On the other hand, consumers are also becoming demographically more demanding in terms of quality, safety and income trends, leading to more affluent consumers to demand for convenience foods such as fresh, pre-cut, pre-cooked and ready-to-eat items, together with assurances of product safety. Production, processing and distribution systems have been adapting to reflect these demands. These trends offer considerable threats for farmers, especially small, asset-poor and disorganized farmers who grow vegetables and fruits.

Malaysian vegetable and fruit industries are important sectors in the economy as they provide fresh food supplies to the population. Its trade performance however has not progressed very much despite the various incentive program provided in the third national agricultural policy. In the case of vegetables, Malaysia is a net importer. For instance, in 2003, Malaysia imported about RM0.7 billion vegetables compared to RM0.2 billion on export in 2002. The production sector however, has responded well to the market demand as shown by the fluctuating acreage between 33,000 44,000 ha in the last decade. In the case of fruits,

Corresponding Author: Norsida Man, Department of Agribusiness and Information System, Faculty of Agriculture, University Putra Malaysia, 43400 Serdang, Selangor, Malaysia 
Malaysia appears to achieve some degrees of selfsufficiency on some selected fruits. The import value for both fruits and vegetables has decreased recently from 2002-2005.

Before the establishment of the hypermarkets in the Malaysian agro-food marketing sector, the marketing of vegetables and fruits is traditional and conventional in its organizational, structural and distributional framework. The marketing channel is characterized by a number of market intermediaries which resulted in high marketing costs. The producers are "isolated" from the "market centers" in the informational sense. That is, market signals are not trickled down to the farm levels hence, the producers are not market responsive. Consequently, farm producers suffer from quality and inconsistent supply problems. Poor market infrastructures aggravate their problems.

At the other end, the food retail industry is moving rapidly in parallel to the change in the developed economy-that is the growth of hypermarkets as the major retail centers for consumers to buy food and consumer goods. This development was brought about by globalization process, in particular the free flow of capital between countries. This development however poses a challenge to the traditional distribution network. The new structure demands fast and efficient delivery, graded, high and consistent quality of produce and consumer-centered marketing strategies.

It is against this background that policy makers, researchers and others are recognizing that the traditional marketing system that concentrates on building up respondents' production capabilities are no longer sufficient to ensure sustainable income and productivity growth. There is now an increasing understanding that production support activities must be linked to market demand and that production activities must be examined within the context of the whole supply chain and the linkages, or business relations, within that chain. There are many types of market linkage arrangements used by small-scale respondents. Contract Farming (CF) is one such linkage that has gained international and national recognition.

Contract farming concept and definitions: The literature review will present various definitions coined by many scholars on contract farming. Contract farming may be defined as agricultural production carried out according to a prior agreement in which the farmer commits to producing a given product in a given manner and the buyer commits to purchasing it. Often, the buyer provides the farmer with technical assistance, seeds, fertilizer and other inputs on credit and offers a guaranteed price for the output (Minot, 2007).
Eaton and Shepherd (2001) definition for contract farming has gained a wide acceptance due to its simplicity and wholesomeness. The FAO views contract farming as "an agreement between farmers and processing and/or marketing firms for the production and supply of agricultural products under forward agreements, frequently at predetermined prices.

While the nucleus of the idea is the same, there are some elaborate definitions worth noting such as the one put forward by Baumann (2000) who refers to contract farming as "a system where a central processing or exporting unit purchases the harvests of independent farmers and the terms of the purchase are arranged in advance through contracts. The terms of the contract vary and usually specify how much produce the contractor will buy and what price they will pay for it. The contractor frequently provides credit inputs and technical advice. Contracting is fundamentally a way of allocating risk between producer and contractor; the former takes the risk of production and the latter the risk of marketing".

Dilating on the Costa Rican experience on contract farming, Pomareda (2006) defines contract farming as "a practice by which agro-industrial processors, exporters, domestic suppliers to supermarkets and other interested actors contract primary production with producers. The practice has grown in variety around the world, for many products, in developed and developing countries. Although generally recognized as beneficial to agricultural producers, processors and exporters, there are arguments in favor of its limitations".

The wide acceptance of contract farming in many parts of the world is a testimony of the vast benefits the arrangement offers and promises to offer to those engaged in it. The report by Sartorius and Kirsten (2006) on the potential benefits of contract farming for the small black farmers in South Africa described the benefits as "a potential 'win-win' situation for government, agribusiness and the agricultural input manufacturers". In fact the benefits are more far reaching than the one suggested above. The prime advantage of a contractual agreement for farmers is that the sponsor will normally undertake to purchase all produce grown, within specified quality and quantity parameters. Contracts can also provide farmers with access to a wide range of managerial, technical and extension services that otherwise may be unobtainable.

Farmers can use the contract agreement as collateral to arrange credit with a commercial bank in order to fund inputs (Eaton and Shepherd 2001). Vertical integration is also another expressed benefit of contract farming. Processors may vertically integrate into farm production or employ production contracts to 
exercise greater control over the quality and timing of deliveries and the quality of inputs used in the production process. Again, reduced risk or greater profits may result. The shifts in risk and associated benefits associated with vertical integration or production contracts depend to a great extent on the nature of the contract and the industry structure.

Typically, the benefits associated with integration or contractual control increase as production and marketing interrelationships become more complex and when breakdowns in marketplace competition are most likely (such as opportunistic behavior by contracting parties) (Hayenga et al., 2000).

Also farmers are majorly entice to enter into contract farming because of the perceived benefits in term of access to market, easy access to credit facilities, better managed risk and provision of information, logistic, extension and necessary transfer of technology from agribusiness (Simmons, 2003).

However, despite these benefits highlighted, there are a number of problems in contract farming. For example, a major problem is that contract farming involving many small and medium producers is characterized high transaction costs which serve as a huge disincentive for the system. Contract farming may be characterized by high transaction costs however still symbolize a better opportunity for expansion of the firm when compared to alternatives (Dietrich, 1994).

Transaction costs are the resources expended in exchange relations, in other words, to agreements to exchange goods or services (i.e., buyer-seller relations). Transaction costs consist thus of the efforts devoted to finding a market, negotiating, signing a contract, controlling contract compliance, switching costs in case of premature termination of the contract and any lost opportunities. In general, three types of transaction costs related to commercial exchange can be distinguished: Search and information costs, bargaining and decision costs and finally supervision and enforcement costs (Eaton et al., 2008).

Sartorius and Kirsten (2006), while dilating on the potential economic benefits of contract farming on small black farmers in South Africa, noted that "the problem of smallholder exclusion is especially problematic in South Africa where historic legacies have contributed to the exclusion off small-scale farmers in the commercial farm sector". There seem to be a general reluctance to streamline black farmer into the supply chain in South Africa by agribusiness due to the transaction cost involve in dealing with them. However, they note further that "agribusiness (through contract farming) can assist small-scale farmers and farmers entering into commercial agriculture to overcome the barriers of entry to high value raw commodities by providing inputs and guaranteed market".

For farmers, the potential problems associated with contract farming include increased risk unsuitable technology and crop incompatibility manipulation of quotas and quality specifications, corruption, domination by monopolies and indebtedness and overreliance on advances. While problems like land availability constraints, social and cultural constraints, farmer discontent, extra-contractual marketing and input diversion are face by sponsors of the contract (Eaton and Shepherd, 2001).

Contract farming can be typified using many bases based on the role played by each in the vertical integration. Discussions of the type of contract farming are often confusing because there are so many different types of contracts and actors (private sector firms, public sector firms and parastatals, international aid agencies) (Baumann, 2000).

The term out grower schemes, for instance, often refers to a scheme in which production and marketing services are provided to farmers on their own land. In their article, Glover and Kusterer (1990) present that these arrangements are generally a government scheme with a public enterprise for purchasing crops from farmers, either on its own or as a joint venture with a private firm. Contract farming is referred to as arrangement in the private sector. Nucleus Estate-Out Grower schemes are arrangements in which a core estate and factory is established and farmers in the surrounding area grow crops on part of their own land, which they sell to the factory for processing. A multipartite arrangement is a term often used in the literature to emphasize the participation of several actors.

In general, contract farming can be typified as market specification contract that is future purchase agreements which determine quantity, timing and price of commodities to be sold. Resource-providing contracts specifies the sorts of crops to be cultivated, some production practices and the quality and standardization of the crop through the provision of technical packages and credits. Production Management Contracts is associated with large out grower and nucleus-estate schemes, directly shape and regulate the production and labor processes of the grower (Baumann, 2000).

While the above literatures are by far a formidable representation for contract farming, subjecting them to a critical review will be worthwhile. Most of the definitions reviewed above seem to be centered on one nucleus-arrangement between independent producer (s) 
and buyer ( $\mathrm{s}$ ) for a predetermined term of production and sales of agricultural products as to quantity, prices, timing and input and management specification. Thus, there seem to be a scholarly accord on the definition though it must be agreed that a considerable difference exist in it. Most of the contention about contract farming lies in the benefit and perception about it. It is generally true that contract farming brings forth a wide array of advantages to farmers, particularly small ones, but there remain some problems.

Contract farming is celebrated for its merits in terms of access to market, easy access to credit facilities, better managed risk and provision of information, logistic, extension and necessary transfer of technology from agribusiness (Simmons, 2003) but this is not always the case.

Randi (1992) observed that unfairness is one of the critical discrepancies of contract framing. Since vertical coordination is viewed as one of the key essence of contract agriculture, its negative impact may over shadow its intrinsic worth. Usually the buyer possesses the power in the vertical integration setup and thus imposes often unrealistic specifications as to the production and management of the agricultural produces. This may include adoption of technology or adherence to timelines of production for producers to follow under minimal assistance and with inferior inputs. This strains the back of the small farmers and challenges the perceived benefit of contract farming scheme.

The idea of contract farming has been in place in Asia for as early as 1960 (Jaffee, 1994). In Malaysia, contract farming was initiated through public farming in 1980s. The scheme started with poultry-based commercial broiler farms. From five companies in 1985, the total number of companies involved increased to 29 in 2004 (Saminathan, 2005). Privately conducted contract farming is frequent, but government agencies such as Department Of Agriculture (DOA) and Federal Agriculture Marketing Authority (FAMA) have also been involved in contract farming (Shaffril et al., 2010). FELCRA in August 2009 expanded its contract farming scheme for cash crops and livestock involving settlers in its land and rural masses nationwide (Bernama, 2009) and as recently as March of this year (2010), Nestle (Malaysia) Bhd. contracted farming of red rice boon to some small village farmers in Sarawak (BORNOEPOST, 2010; Cai et al., 2008). There are ample indications of the growing acceptance of contract farming in Malaysia. Currently, an area of 1,963 ha was allocated to develop contract farming activities which is expected to exceed 35,924 ha in year 2010. It expects to involve of 22,243 respondents and generates RM 4.3 billion value added.
The type of CF that FAMA engages for farmers is market specification contract, which is a pre-harvest agreement between producers and contractors on the conditions of governing the sale of the crop. Contract farming is seen to have increased the market access and information of the farmers in Malaysia. However, there are evidences to show that small farmers are not able to meet the strict quality requirement of the retail chains. For instance, the giant supermarket Chains had 200 vegetable suppliers in 2001 but by 2003 this was down to 30 (Reardon et al., 2003). Similar problems have been reported on the contracts between suppliers and retail chains. With the current structural problems that are prevailing in the small farm sector, it begs the questions as to the ability of the small respondents to meet the rigid demands of the buyers and large retailers.

The research questions addressed in this study are:

- Why the CF concept is not widely applied along SCM for fruit and vegetables respondents?

- What are the opportunities and risks of $\mathrm{CF}$ for farmers and firms?

- What are the types of CF exist in Malaysia?

- How can small farmers develop some form of quality assurance system for their output and establish trust and reputation?

- How do small farmers deal with environmental regulations and issues?

- Will contract farming and vertical integration be the mechanisms smallholder-producers need to meet the new requirements, be recognized as producing safe food and overcome the high cost of compliance with food safety and quality standards, high capital and small-scale input?

The overall objective of this study is to examine the contract farming as the new marketing practice among selected vegetables and fruits on respondents. The specific objectives are: (1) to examine the perception of respondents towards contract farming; (2) to identify respondents practices toward the contract farming and (3) to evaluate the critical success and failure factors of CF and (4) to suggest policy issues for the sustainability of contract farming.

The scope of the study is to examine the contract farming and vertical integration provide small vegetable and fruit famers with a more efficient means to remain competitive in the presence of the changing demand for quality and food safety relative to open markets. A special focus is given to the evaluation of buyerproducer relationships at all levels, in particular, the implications on producers' access to the market and negotiating power. An economic analysis of the 
advantages and disadvantages of contract production will be made. The implications of demand on high quality agricultural produce on small producers are examined.

\section{MATERIALS AND METHODS}

The study is based on the 2007 Supply Chain Management (SCM) survey on fruits and vegetable supply chain where a total of 208 respondents were interviewed from seven (7) states in Peninsular Malaysia by using structured question and the results of the survey were obtained using SPSS. Out of the 208 respondents, 41 respondents are practicing contract farmer. The structured questionnaires are divided into two sections: Section one is for contract and noncontract respondents and section two is for contract respondents. In this study, we are focused on contract respondents only.

Selected production and market centers for fresh agricultural produce in peninsular Malaysia targeted for the purpose of data collection. Primary data for this study was collected through a market survey on selected market participants like vegetable and fruit respondents, retailers (hypermarkets, supermarkets, supermarket chains and discount stores), wholesalers, processors, packers, input suppliers, assemblers and producers. A special focus will be given on the buyerproducer relationship particularly the CF processes in terms of performance (e.g., replenishment lead time), quantity and size, supply quality, transportation, pricing terms, information coordination and supplier viability. The nature and terms of contract between farmers, buyer and supplier were examined. The statistical tools that will be used include descriptive and multivariate analyses.

After a visual examination, responses from the completed questionnaires were entered into the Statistical Package for Social Sciences (SPSS) program. Open-ended responses were first encoded before entering into SPSS. The frequency distributions for each question were run to check for any inaccuracies in the entry process and to test for the normality of the data, After correcting for any data entry errors, the frequency distributions provided the major data input for the table used to describe the respondents.

Due to the nature of this study, univariate data analysis techniques were primarily used. For univariate data analysis, measures such as the central location, frequency distribution and variability were calculated for each question. These types of statistical analyses are useful in describing the data, identifying the location of the central point and for defining how various aspects of the data are related. In this study, descriptive statistics were widely used to describe the sociodemographic background of the respondents.

\section{RESULTS AND DISCUSSION}

Among 208 respondents, $19.7 \%$ of the respondents practices contract farming and $80.3 \%$ of the respondents does not involve in contract farming (Table 1).

Table 2 shows that $17.1 \%$ of the respondents participates in production contract and $82.9 \%$ of the respondents participates in marketing contract. Figure 1 illustrates that $56.1 \%$ of the respondents has a contract with the Federal Agricultural Marketing Authority (FAMA).

$19.5 \%$ of the respondents has a contract with the wholesalers, followed by $9.8 \%$ of the respondents has a contract with hypermarkets and $7.3 \%$ of the respondents has a contract with the collectors (Fig. 1).

The finding shows that $73.2 \%$ of the respondents have formal or written agreements with the sponsors and $26.8 \%$ of the respondents have verbal or mutual agreements with the sponsors (Table 3 ).

Table 1: Practice contract farming

\begin{tabular}{lcc}
\hline Items & Frequency & Percentage \\
\hline Yes & 41 & 19.7 \\
No & 167 & 80.3 \\
Total & 208 & 100.0 \\
\hline
\end{tabular}

Table 2: Type of contract farming

\begin{tabular}{lcl}
\hline Type of contract farming & Frequency & Percentage \\
\hline Production & 7 & 17.1 \\
Marketing & 34 & 82.9 \\
\hline
\end{tabular}

Table 3: Types of contract

\begin{tabular}{lll}
\hline Types & Frequency & Percentage \\
\hline Formal & 30 & 73.2 \\
Verbal & 11 & 26.8 \\
\hline
\end{tabular}

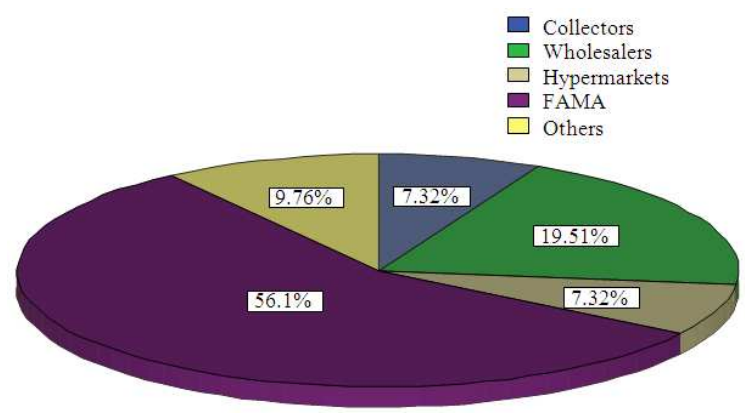

Fig. 1: Sponsors of contract farming 
Am. J. Agri. \& Biol. Sci., 5 (3): 321-330, 2010

Table 4: Reasons for participating in contract farming

\begin{tabular}{|c|c|c|c|c|}
\hline \multirow[b]{2}{*}{ Reasons } & \multicolumn{2}{|c|}{ Yes } & \multicolumn{2}{|c|}{ No } \\
\hline & $\mathrm{n}$ & $(\%)$ & $\mathrm{n}$ & $(\%)$ \\
\hline Market access & 29 & 70.7 & 12 & 29.3 \\
\hline Price protection & 33 & 80.5 & 8 & 19.5 \\
\hline Credit support & 18 & 43.9 & 23 & 56.1 \\
\hline Technical and extensions services & 16 & 39.0 & 25 & 61.0 \\
\hline Guaranteed markets & 35 & 85.4 & 6 & 14.6 \\
\hline Increased competitive edge & 18 & 43.9 & 23 & 56.1 \\
\hline Guaranteed stable income & 34 & 82.9 & 7 & 17.1 \\
\hline High quality produce & 24 & 58.5 & 17 & 41.5 \\
\hline
\end{tabular}

Table 5: Formal and verbal specifications in contract farming

\begin{tabular}{lrrrr}
\hline & \multicolumn{3}{c}{ Yes } & \multicolumn{1}{l}{ No } \\
Specifications & \multicolumn{1}{c}{$\mathrm{n}$} & $(\%)$ & \multicolumn{1}{c}{$\mathrm{n}$} & $(\%)$ \\
\hline Quantity of produce & 24 & 58.5 & 17 & 41.5 \\
Quality of produce & 32 & 78.0 & 9 & 22.0 \\
Delivery date & 19 & 46.3 & 22 & 53.7 \\
Amount of fertilizer used & 5 & 12.2 & 36 & 87.8 \\
Amount of pesticide used & 9 & 22.0 & 32 & 78.0 \\
Method of payments & 20 & 48.8 & 21 & 51.2 \\
Duration of contract & 14 & 34.1 & 27 & 65.9 \\
Quality standards & 27 & 65.9 & 14 & 34.1 \\
Pricing arrangements & 17 & 41.5 & 24 & 58.5 \\
Cultivation practices & 10 & 24.4 & 31 & 75.6 \\
Payment procedures & 17 & 41.5 & 24 & 58.5 \\
Insurance arrangements & 1 & 2.4 & 40 & 97.6 \\
\hline
\end{tabular}

A total of 41 respondents participate in the contract farming. About $70.7 \%$ of the respondents inform that the reasons for them to participate in the contract farming are easy market access. About $80.5 \%$ of the respondents reports that the price of produce is protected. About $43.9 \%$ of the respondents states that they are provided with a credit support by the sponsors. About $39.0 \%$ of the respondents agree that the technical and extensions services are provided by the sponsors. $85.4 \%$ of the respondents inform that the market is guaranteed by the sponsors (Table 4).

By engaging in contract farming, $43.9 \%$ of the respondents believe that it will increase their competitive edge. About $82.9 \%$ of the contracted respondents inform that their income is guaranteed. About $58.5 \%$ of the respondents reports that they can produce high quality vegetables and fruits.

About $58.5 \%$ of the contact respondents inform that quantity is one of the specifications in contract farming. About $78 \%$ of the respondents agrees that quality of the produce also one of the specifications. About $65.9 \%$ of the respondents state that a quality standard is one of the specifications included in contract farming (Table 5).

Figure 2 illustrates the duration for the produce payments. About $48.8 \%$ of the respondents inform that the sponsors pay the respondents between 1-10 days. About $14.6 \%$ of the respondents reports that they are paid by the sponsors between 11-20 days.

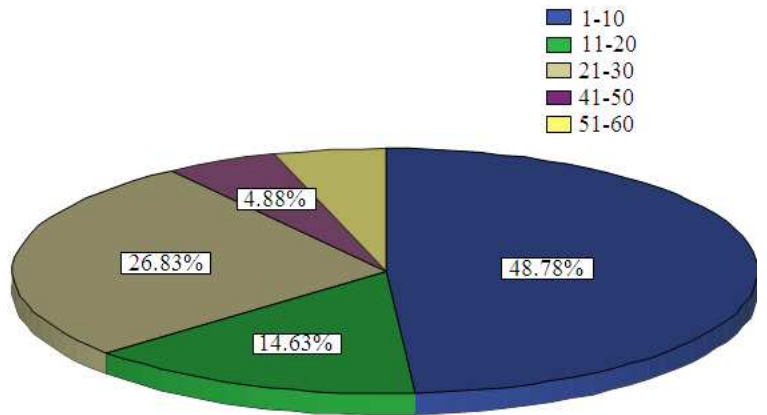

Fig. 2: Duration for produce payments

About $26.8 \%$ of the respondents inform they are paid between $21-30$ days and $4.9 \%$ of the respondents states that they were paid between 41-50 days.

Table 6 shows the attitude of respondents toward contract farming. The finding shows that 78 of the respondents inform that they will participate in contract farming if the buyers offer a high price. Sixty three of the respondents strongly agree if the provide buyers a fair income. Forty eight of the respondents agree if the buyers give a fair income, they will consider participating in the contract farming. Eleven of the respondents inform that they do not have any opinion on the statement. Fifteen of the respondents inform that they disagree with the statement and 30 of the respondents strongly disagree with the statements.

On the third statement if the buyers buy all the produce, 63 of the respondents strongly agree with the statement, 38 of the respondents agree to the statement; 18 of the respondents do not have any opinion regarding the statements, 28 of the respondents disagree with the statements and 20 of the respondents strongly disagree with the statement. If the buyers introduce appropriate technology to upgrade agricultural commodities, 47 of the respondents strongly agree to that statements and 48 of the respondents agree to the statement. 25 of the respondents do not have any opinion on the statement. Eighteen of the respondents disagree with the statement and 29 of the respondents strongly disagree with the statement.

On the statement if the buyers provide market information, 55 of the respondents strongly agree to the statement, 51 respondents agree to the statement, 15 of them do not have any opinion on the statement, 27 of the respondents disagree to the statement and 19 respondents strongly disagree with the statement. If the buyers provide loan or credit to finance production inputs, 52 of the respondents strongly agree to this statement, 45 of the respondents agree to the statement, 19 of them do not have any opinion, 19 of the respondents disagree and 32 of the respondents strongly disagree to the statement. 
Table 6: Attitude towards contract farming

\begin{tabular}{|c|c|c|c|c|c|}
\hline \multirow[b]{2}{*}{ Items } & \multicolumn{5}{|c|}{ Score } \\
\hline & 1 & 2 & 3 & 4 & 5 \\
\hline If the buyers buy higher than the market price & 78 & 32 & 9 & 26 & 22 \\
\hline If the buyers give stable income and price & 63 & 48 & 11 & 15 & 30 \\
\hline If the buyers buy all the produce & 63 & 38 & 18 & 28 & 20 \\
\hline If the buyers provide appropriate technology to enhance agriculture productivity & 47 & 48 & 25 & 18 & 29 \\
\hline If the buyers provide market information & 55 & 51 & 15 & 27 & 19 \\
\hline If the buyers provide loan or credit to finance production inputs & 52 & 45 & 19 & 19 & 32 \\
\hline If the buyers provide extension on production & 48 & 49 & 21 & 26 & 23 \\
\hline If the buyers provide reliable inputs & 54 & 46 & 18 & 17 & 32 \\
\hline
\end{tabular}

Note: 1: Strongly agree; 2: Agree; 3: No opinion; 4: Disagree; 5: Strongly disagree

Table 7: Disadvantages of contract farming

\begin{tabular}{lcr}
\hline Items & Frequency $(\mathrm{n}=38)$ & $(\%)$ \\
\hline Delay in payment & 29 & 76.3 \\
High requirement & 7 & 18.4 \\
Unhappy with the price & 2 & 5.3 \\
\hline
\end{tabular}

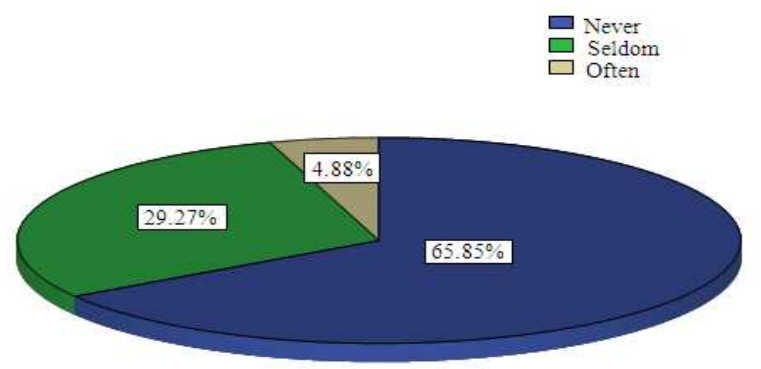

Fig. 3: Conflicts between respondents and sponsors

Forty eight of the respondents strongly agree if the buyers provide marketing information and production, 49 of the respondents agree; 21 of the respondents have no opinion on the statement; $26^{\circ}$ to the statement and 23 of them strongly disagree. To the statement of If the buyers provide reliable inputs, 54 of the respondents strongly agree to the statement; 46 of them agreed; 18 of them do not have any opinion; 17 of them disagree to the statement and 32 of the respondents strongly disagree to the statement.

Table 7 illustrates that the disadvantages of contract farming. About $76.3 \%$ of the respondents inform that usually the payment for the produce is always delayed. About $18.4 \%$ of the respondents state that there is a high requirement from the sponsors. About 5.3\% of the respondents report that they were not happy with the price that offers by the sponsors.

Figure 3 illustrates that $65.9 \%$ of the respondents informs that they have never had conflicts with the sponsors. About $29.3 \%$ of the respondents states that they seldom have had conflicts with the sponsors and $4.9 \%$ of the respondents reports that they often have had conflicts with the sponsors.
Table 8: Reasons for conflicting

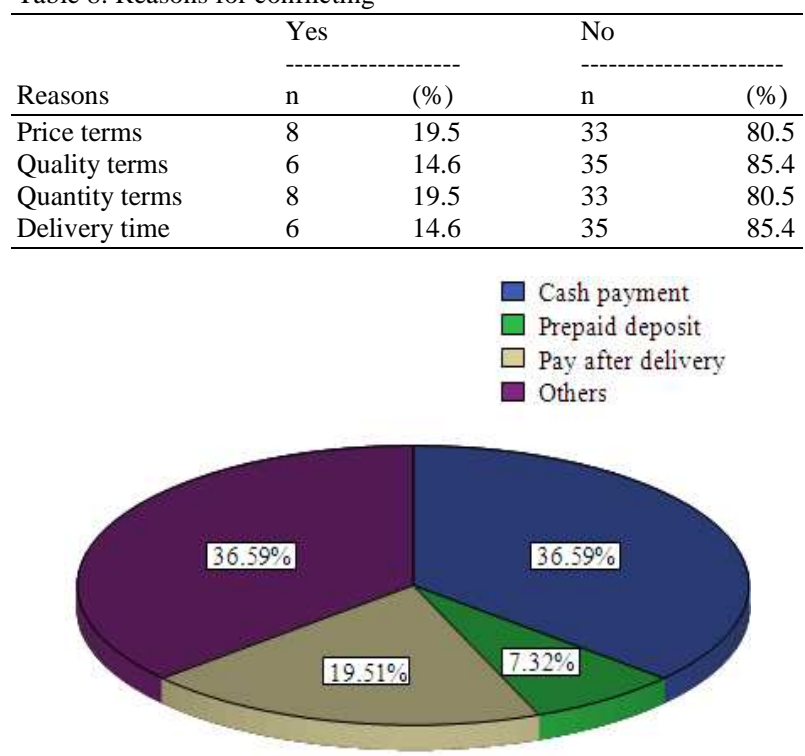

Fig. 4: Payment methods

About $19.5 \%$ of the respondents cite that the price terms and quantity terms are the reason for having conflicts with the sponsors. About $14.6 \%$ of the respondents inform that the quality terms and delivery time are the reasons for conflicting (Table 8).

Figure 4 illustrates that $36.6 \%$ of the respondents informs that they receive cash payment from the sponsors. About $19.5 \%$ of the respondents states that they receive money after the delivery.

Table 9 illustrates the attitude of respondents towards contract farming. Nineteen respondents out of 41 respondents strongly agree that the sponsors normally undertake to purchase all produce, 17 of the respondents just agree to the statement and 5 of them disagree with the statement. On the statement contracts can also provide respondents with access to managerial, technical and extension services, 15 of the respondents strongly agree, 16 respondents agree, 3 respondents have no opinion on it, 4 respondents disagree and 3 respondents strongly disagree with the statement. 


\begin{tabular}{|c|c|c|c|c|c|}
\hline \multirow[b]{2}{*}{ Items } & \multicolumn{5}{|c|}{ Score } \\
\hline & 1 & 2 & 3 & 4 & 5 \\
\hline Sponsors normally undertake to purchase all produce & 19 & 17 & - & 5 & - \\
\hline Contracts can also provide respondents with access to managerial, technical and extension services & 15 & 16 & 3 & 4 & 3 \\
\hline Introduction to appropriate technology to upgrade agricultural commodities & 8 & 13 & 7 & 10 & 3 \\
\hline Gain access to markets & 19 & 18 & - & 4 & - \\
\hline Improve quality of produce & 15 & 20 & 3 & 3 & - \\
\hline Stable income & 17 & 21 & - & 3 & - \\
\hline Reduce marketing risk & 19 & 19 & 1 & 2 & - \\
\hline Easy access to marketing information and extension services & 11 & 17 & 8 & 5 & - \\
\hline Gain access to loans or credit to finance production inputs & 7 & 7 & 13 & 12 & 2 \\
\hline Inputs and production services are supplied by the buyer & 4 & 17 & 7 & 11 & 2 \\
\hline Acquire knowledge for use on new crops & 9 & 11 & 13 & 6 & 2 \\
\hline Reliable supplies inputs & 11 & 14 & 6 & 8 & 2 \\
\hline Do not have to worry about marketing produce & 16 & 19 & 1 & 4 & 1 \\
\hline Guaranteed minimum prices & 20 & 13 & 5 & 1 & 2 \\
\hline Skill transfer such as record keeping & 6 & 21 & 8 & 6 & - \\
\hline The efficient use of farm resources & 8 & 19 & 8 & 6 & - \\
\hline Improved method of applying chemicals and fertilizers & 10 & 16 & 6 & 8 & 1 \\
\hline Contract farming can open up new markets & 15 & 19 & 5 & 2 & - \\
\hline Protect respondents from incurring losses in sales due downward price fluctuations & 13 & 24 & 3 & 1 & - \\
\hline
\end{tabular}

Note: 1: Strongly agree; 2: Agree; 3: No Opinion; 4: Disagree; 5: Strongly disagree

Table 10: Type of contract farming * categories of bodies cross tabulation

\begin{tabular}{|c|c|c|c|c|c|c|c|}
\hline & & \multicolumn{6}{|c|}{ Categories of bodies } \\
\hline \multicolumn{2}{|c|}{ Type of contract farming } & Collectors & Wholesalers & Hyper-markets & FAMA & Others & Total \\
\hline \multirow[t]{2}{*}{ Production } & Count & 0 & 3 & 2 & 1 & 1 & 7 \\
\hline & Within categories of bodies $(\%)$ & $0.0 \%$ & $7.32 \%$ & 4.88 & 2.44 & 2.44 & $17.07 \%$ \\
\hline \multirow[t]{2}{*}{ Marketing } & Count & 3 & 5 & 1 & 22 & 3 & 34 \\
\hline & Within categories of bodies (\%) & $7.32 \%$ & $12.20 \%$ & $2.44 \%$ & $53.66 \%$ & $7.32 \%$ & 82.9 \\
\hline \multirow[t]{2}{*}{ Total } & Count & 3 & 8 & 3 & 23 & 4 & 41 \\
\hline & Within type of contract farming (\%) & $7.32 \%$ & $19.5 \%$ & $7.3 \%$ & $56.1 \%$ & $9.8 \%$ & $100.0 \%$ \\
\hline
\end{tabular}

Only 8 of the respondents strongly agree that contract farming introduce to appropriate technology to upgrade agricultural commodities. Thirteen of the respondents just agree to that statement and 10 of the respondents disagree to the statement. Nineteen of the respondents strongly agree that contract farming easily gain access to the market and 18 respondents just agree to the statement.

Most of the respondents agree that contract farming improve quality of produce and the income is stable. They also agree that contract farming reduce marketing risk. Eleven respondents strongly agreed that contract farming create a path where respondents easily can access to the marketing information and extensions services. Seventeen of the respondents agree to the statement and 5 of the respondents disagree with the statement.

On the statement that inputs and production services are supplied by the buyer; 4 respondents strongly agree, 17 respondents just agree, 7 respondents have no opinion, 11 respondents disagree with the statement and 2 respondents strongly disagree. Twenty five of the respondents agree that by practicing contract farming they received reliable inputs. Most respondents agree by practicing contract farming they not worry about the marketing of produce. Most respondents also agree that by practicing contract farming, contract farming can open up new markets and protect respondents from incurring losses in sales due downward price fluctuations.

From Table 10, $82.9 \%$ of the contract respondents are involved in marketing contract. Respondents $(7.32 \%)$ in the production contract mostly sell their products to wholesalers while $53.6 \%$ of respondents in marketing contract have a contract with FAMA. The table also indicates that $56.1 \%$ of the respondents in the contract farming have contracts with FAMA.

From Table 11, 68.3\% of the contract respondents are involved in vegetable farming of which $58.54 \%$ is marketing contract. Fruit contract respondents constitute $24.39 \%$ of the total contract respondents who are involved in marketing contract. Since the table also indicates that only $17 \%$ of contract respondents are involved in the production contract, establishing a task force to study production contract respondents was probably important. 
Am. J. Agri. \& Biol. Sci., 5 (3): 321-330, 2010

Table 11: Type of products category * type of contract farming cross tabulation

\begin{tabular}{|c|c|c|c|c|}
\hline \multirow[b]{2}{*}{ Product category } & & \multicolumn{3}{|c|}{ Type of contract farming } \\
\hline & & Production & Marketing & Total \\
\hline \multirow[t]{2}{*}{ Vegetable $(\mathrm{C})$} & Count & 4.00 & 24.00 & 28.0 \\
\hline & Within what type of contract farming that you involved in (\%)? & 9.76 & 58.54 & 68.3 \\
\hline \multirow[t]{2}{*}{ Fruits $(\mathrm{C})$} & Count & 3.00 & 10.00 & 13.0 \\
\hline & Within what type of contract farming that you involved in $(\%)$ ? & 7.32 & 24.39 & 31.7 \\
\hline \multirow[t]{2}{*}{ Total } & Count & 7.00 & 34.00 & 41.0 \\
\hline & Within type of category $(\%)$ & 17.10 & 82.90 & 100.0 \\
\hline
\end{tabular}

\section{CONCLUSION}

Data from 41 contract respondents are analyzed using SPSS to describe the respondents profile and current supply chain practices. From the result, it can be determined that at present the respondents have contract agreement with FAMA and FAMA has a contract agreement with hypermarkets. It is presumed that there is a new supply chain network but the contract is not in line with FAO definition. The production and marketing contracts exist in non-formal or mainly verbal agreement.

On further scrutinizing the data, the production contract respondents also do not follow the criteria of contract farming. For example, sponsors do not supply the inputs needed. Most respondents buy their own seeds, fertilizer and chemicals. Respondents do not brand their products and therefore do not follow the stringent requirement of hypermarkets. Because of this, all the non-formal production contracts in this survey are categorized into marketing contracts. In conclusion, there is no proper contract farming exist between respondents and hypermarkets.

Since respondents dislike contract farming due to complicated process, few respondents send their produce to wholesalers i.e., following the traditional supply chain. As a result, hypermarkets are also seen buying from traditional supply chain because of no contract farming agreements. In order to get respondents' perception on their participation on the proposed new supply chain network, several dimensions were obtained from the results of factor analysis.

Based on these dimension, it can be concluded that respondents are willing to participate if they can receive all the benefits as stated above. With this in mind, the proposed new supply chain network should involve new players to safeguard the interest of respondents when executing contracts. The involvement of new middlemen like respondent cooperative as collectors, packers and transporters should be encouraged. The possible linked in the new supply chain would be respondents get together to form an association or a cooperative and then these organizations would have contract agreements with hypermarkets and other middlemen. At the same time, they would also have a contractual agreement with suppliers in the input sector to supply inputs at competitive prices.

\section{REFERENCES}

Baumann, P., 2000. Equity and efficiency in contract farming schemes: The experience of Agricultural tree crops. Overseas Development Institute. http://www.odi.org.uk/resources/download/2022.pdf

Bernama, 2009. Felcra to expand contract farming programme. Malaysian National News Agency. http://fama.bernama.com/news.php?lang=\&id=430 744

BORNOEPOST, 2010. Red rice boon to 40 contract farmers. BORNEOPOST Online. http://www.theborneopost.com/?p=15506

Cai, J., L. Ung, S. Setboonsarng and P. Leung, 2008. Rice contract farming in Cambodia: Empowering farmers to move beyond the contract toward independence. $\quad \mathrm{ADB}$ Institute. http://www.fao.org/uploads/media/ADBI\%20contr act $\% 20$ farming $\% 20$ rice $\% 20$ cambodia.pdf

Dietrich, M., 1994. Transaction Cost Economics and Beyond. 1st Edn., Routledge, London, ISBN: 10: 0415071550, pp: 232.

Eaton, C. and A.W. Shepherd, 2001. A guide, contract farming-partnership for growth. FAO Agric. Serv. Bull., 145: 1-182.

Eaton, D., G. Meijerink and J. Bijman, 2008. Understanding institutional arrangements: Fresh Fruit and Vegetable value chains in East Africa. WAGENINGERUR.

http://www.boci.wur.nl/NR/rdonlyres/98CCE2E30FA2-4274-BCA020713CA1E125/67705/Fullreport11_Bijman_Eato n_Meijerink.pdf

Glover, D. and K. Kusterer, 1990. Small Farmers, Big Business: Contract Farming and Rural Development. 1st Edn., Macmillan, New York, pp: 170. 
Hayenga, M.L., N.E. Harl and J.D. Lawrence, 2000. Impact of increasing production or marketing contract volume on access to competitive markets. Iowa State University. http://econpapers.repec.org/paper/isugenres/10565. htm

Jaffee, S.M., 1994. Contract Farming in the Shadow of Competitive Markets: The Experience of Kenyan Horticulture. In: Living Under Contract, Contract Farming and Agrarian Transformation in SubSahara Africa, Little, P.D. (Ed.). University of Wisconsin Press, Wisconsin, ISBN: 10: 0299140644, pp: 167-187.

Minot, N., 2007. Contract farming in developing countries: Patterns, impact and policy implications. Cornell University Library. http://cip.cornell.edu/dns.gfs/1200428173

Pomareda, C., 2006. Contract agriculture lessons from experiences in Costa Rica. RIMISP. http://www.rimisp.org/getdoc.php?docid=6472

Randi I.R., 1992. Contract farming breeds big problems for growers. Farmers' Legal Action Group, Inc. http://www.flaginc.org/topics/pubs/arts/artcf002.pdf
Reardon, T., C.P. Timmer, C.B. Barrett and J. Berdegue, 2003. The rise of supermarkets in Africa, Asia and Latin America. Am. J. Agric. Econ., 85: 1140-1146.

Saminathan, S., 2005. Sustainable contract farming for increased competitiveness: Case study on poultry sector in Sarawak, Malaysia. National Productivity Corporation.

http://www.fao.org/uploads/media/Contract_farmin g_of_poultry_in_Malaysia_1.pdf

Sartorius, K. and J. Kirsten, 2006. Contracts and contract farming as potential mechanisms to improve market access for black farmers in South Africa. Food, Agriculture and Natural Resources Policy Analysis Network. http://www.fanrpan.org/documents/d00692/

Shaffril, H.A.M., J.L. D'Silva, J.U. and B.A. Samah, 2010. Gender issue in contract farming: The case of Malaysian students. Am. J. Agric. Biol. Sci., 5: 204-209.

Simmons, P., 2003. Overview of smallholder contract farming in developing countries. FAO. ftp://ftp.fao.org/docrep/fao/007/ae023e/ae023e00.pdf 